adequate topical analgesia of the larynx and intravenous dexamethasone may help to reduce laryngeal oedema.

The emergency department physician should, therefore, consider subglottic impaction of the aspirated foreign body in cases with sudden onset of dyspnoea with odynophagia. Soft tissue neck radiographs are the most useful investigation but should be done under proper supervision of the patient and in the presence of a doctor capable of performing an emergency tracheostomy in a child. There is need for a programme to educate the public in the proper first aid measures when dealing with victims of aspirated foreign bodies. This will prevent the kind of complications that were seen in our cases.

1 National Safety Council. Accident facts. Itasca, IL: Nationa Safety Council, 1995.

2 Banerjee A, Rao S, Khanna SK, et al. Laryngo-tracheobronchial foreign body in children. $\mathcal{f}$ Laryngol Otol

$3 \mathrm{Mu} \mathrm{L}$, He P, Sun D. Inhalation of foreign bodies in Chinese children: a review of 400 cases. Laryngoscope 1991;101: children: a review of 400 cases. Laryngoscope 1991;101:

Svensson G. Foreign bodies in tracheobronchial tree.
Special references to experience in 97 children. Int $\mathcal{f}$ PediSpecial references to experience in 97
atr Otorhinolaryngol $1985 ; 8: 243-51$

5 Cohen SR, Lewis GB, Herbert WI, et al. Foreign bodies in airway. Ann Otol Rhinol Laryngol 1980;89:437-42.

$6 \mathrm{Kim}$ IG, Brummitt WH, Humphry A, et al. Foreign body in the airway - a review of 202 cases. Laryngoscope $1973 ; 83$. 347-54.
7 Krejovic B, Cvetkovic S, Popovic S. Les corps etrangers du larynx. Fournal Francais d'Oto-Rhino-Laryngologie 1981;30: $465-8$.

8 Rothmann BF, Boeckman CR. Foreign bodies in the larynx and tracheobronchial tree in children. Ann Otol Rhino Laryngol 1980;89:434-6.

9 Harris CS, Baker SP, Smith GA, et al. Childhood asphyxiation by food-a national analysis and overview. $\mathscr{F} A M A$ 1984;251:2231-5.

10 Darrow DH, Holinger LD. Foreign bodies of the larynx trachea and bronchi. In: Bluestone CD, Stool S, Kenna MA, eds. Paediatric otolaryngology. 3rd Ed. Philadelphia: WB Saunders, 1996: 1394.

11 Brama I, Fearon B. Laryngeal foreign bodies in children. In f Pediatr Otorhinolaryngol 1982;4:259-65.

12 Esclamado RM, Richardson MA. Laryngotracheal foreign bodies in children. Am 7 Dis Child 1987;141:259-62.

13 Halvorson D, Merritt RM, Mann C, et al. Management of subglottic foreign bodies. Ann Otol Rhinol Laryngol 1996;105:541-4.

14 Battersby EF. Paediatric anaesthesia. Scott-Brown's otolaryngology. Volume 6. 5th Ed. London: Butterworth, 1987: 503-26.

15 Standards and Guidelines for Cardiopulmonary Resuscitation (CPR) and Emergency Cardiac Care (ECC). National Academy of Sciences-National Research Council. $\mathfrak{f} A M A$ 1986;255:2905-89.

16 Heimlich HJ. A life-saving maneuver to prevent foodchoking. FAMA 1975;234:398-401.

17 Kent SE, Watson MG. Laryngeal foreign bodies. $f$ Laryngo Otol 1990;104:131-3.

18 Moskowitz D, Gardiner LJ, Sasaki CT. Foreign body aspiration. Potential misdiagnosis. Arch Otolaryngol Head Neck Surg 1982;108:806-7.

19 McGuirt WF, Holmes KD, Feehs $R$, et al. Tracheobronchial foreign bodies. Laryngoscope 1988;98:615-8.

20 Woods A. Paediatric bronchoscopy, bronchography, and larygoscopy. In: Berry FA, ed. Anaesthetic management of difficult and routine paediatic patients. New York: Churchil Livingstone, 1986: 189-247.

\title{
An acutely painful elbow as a first presentation of von Willebrand's disease
}

\author{
H D M Poncia, J Ryan
}

\section{Department of Accident and Emergency Medicine, Royal Sussex County Hospital, Eastern Road, Brighton BN2 5BE \\ H D M Poncia J Ryan}

Correspondence to: Mr Ryan (e-mail: ryanj@pavilion.co.uk).

\begin{abstract}
A 26 year old woman presented to the accident and emergency department with a painful right elbow. There had been no history of trauma. Clinical examination suggested an effusion, which was confirmed on radiological examination. Her elbow was aspirated and revealed a haemarthrosis. Subsequent investigations revealed a diagnosis of von Willebrand's disease (vWD). A spontaneously occurring effusion of the elbow may be due to a haemarthrosis. Aspiration of blood in the absence of trauma may lead to a diagnosis of an occult coagulopathy in addition to relieving pain. The diagnosis and treatment of vWD is discussed. ( 7 Accid Emerg Med 1999;16:153-154)
\end{abstract}

Keywords: von Willebrand's disease; haemarthrosis; elbow

\section{Case report}

A 26 year old woman, normally fit and well, presented to the accident and emergency (A\&E) department with a painful right elbow. Symptoms had developed spontaneously over- night and she attributed them to sleeping in an awkward position. Her elbow was held in a flexed position. Flexion and extension were both restricted. Radiographs were taken which showed prominent anterior and posterior fat pads (fig 1 ). A synovial effusion was suspected and her elbow was aspirated to provide symptomatic relief. Surprisingly, aspiration of the joint produced $7 \mathrm{ml}$ of blood. She was given a broad arm sling to rest her elbow. One week later her elbow was much improved and full extension was only limited by 10 degrees. At six weeks her elbow was back to normal.

On further questioning the patient gave a history of occasional bruising and heavy periods during the previous 2-3 years. She was on no medication. Her mother also had a history of bruising. In view of this history and the findings of a spontaneous haemarthrosis, she was referred for a haematological assessment.

Investigations revealed a normal full blood count, liver function, biochemistry, international normalised ratio, and activated partial thromboplastin time ratio. However von Willebrand factor ( $v W F$ ) antigen and vWF activity were low, $31 \mathrm{IU} / 100 \mathrm{ml}(50-200)$ and 29 


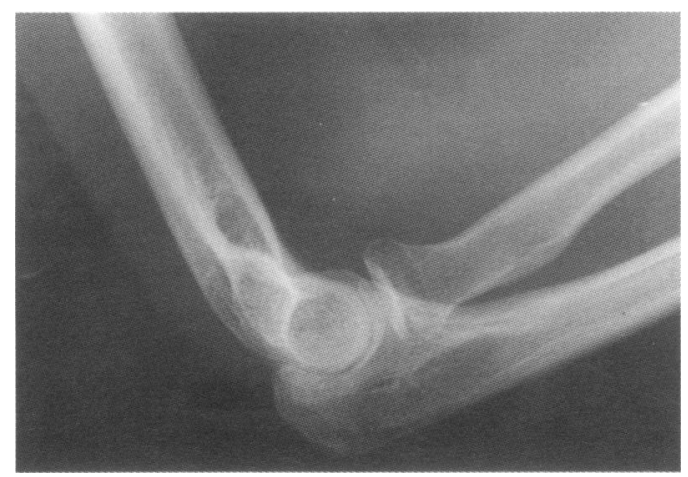

Figure 1 Lateral radiograph of elbow showing a raised fat pad.

IU/100 ml (50-200) respectively. Factor VIII:c was normal, $70 \mathrm{IU} / 100 \mathrm{ml}(50-200)$. These were repeated three months later: $\mathrm{vWF}$ antigen was $22 \mathrm{IU} / 100 \mathrm{ml}$, vWF activity $35 \mathrm{IU} / 100 \mathrm{ml}$, and factor VIII:c $62 \mathrm{IU} / 100 \mathrm{ml}$, confirming a diagnosis of von Willebrand's disease (vWD).

\section{Discussion}

Haemarthrosis of the elbow is common in haemophilia A and may occur in up to $90 \%$ of patients, however it is relatively uncommon in vWD. It is extremely painful and if untreated may take days to resolve. Long term consequences of repeatedly exposing joint surfaces to blood include accelerated destruction of cartilage and hypertrophic osteoarthropathy with marked bony deformity and ankylosis.

The usual method of elbow aspiration involves a posterolateral approach as described by Gaston et al in $1949 .{ }^{1}$ The patient is first positioned supine with the arm abducted 45-90 degrees and the shoulder and elbow flexed 90 degrees with the palm placed flat on a table. This position of pronation helps to protect the radial nerve. The skin is then cleansed and infiltrated with $1-3 \mathrm{ml}$ of $2 \%$ lignocaine. An 18 or 20 gauge needle on a 5-10 $\mathrm{ml}$ syringe is then inserted into the midpoint of the triangle bordered by the radial head, olecranon and lateral humeral epicondyle. ${ }^{2}$

vWD was first described in 1926. It is a heterogeneous disorder with many distinct subgroups. Inheritance is usually autosomal dominant, the gene for vWF being located on chromosome 12, but it may also be autosomal recessive or acquired. Acquired vWD is rare but may occur with lymphoproliferative disorders, ${ }^{34}$ autoimmune diseases, hypothyroidism, and treatment with drugs such as valproate. Classically vWD presents with a mild to moderately severe mucocutaneous bleeding tendency, bruising, epistaxis, menorrhagia, and bleeding from minor cuts. Patients may present in their 20 s or 30 s with prolonged bleeding after dental extraction. ${ }^{5}$

vWD is caused by abnormal, deficient, or defective production of vWF, which normally acts as a protective carrier for factor VIII in the circulation as well as being involved in platelet adhesion. Reduced levels of vWF lead to reduced plasma levels of factor VIII and prolonged bleeding times. Before release vWF is stored within endothelial cells and platelets. ${ }^{6}$ Stored vWF can be released by triggers such as insulin, adrenaline, and vasopressin. An increase in vWF occurs as part of the acute phase response to inflammation, injury, infection, neoplasia, and pregnancy. Thus in order to be sure of the diagnosis it is important to perform carefully standardised sets of assays on at least two separate occasions, with the patient in a "steady state".

The laboratory diagnosis of vWD is made on the basis of immunological and functional studies of vWF, factor VIII concentrations, and electrophoretic analysis. ${ }^{7}$ Considerable progress has been made in characterising the specific molecular defects responsible for this heterogeneous disorder. The problems of incomplete vWD penetrance and poor diagnostic sensitivity and accuracy for the currently available clinical laboratory tests provide a strong incentive for developing DNA based diagnostics. ${ }^{8}$

The mainstay of treatment for most patients with type $1 \mathrm{vWD}$ is desmopressin (1-deamino8-D-arginine, DDAVP), a synthetic analogue of the antidiuretic hormone L-arginine vasopressin. Desmopressin stimulates the release of vWF from vascular endothelial cells and produces a rise in factor VIII concentrations. Factor VIII and von Willebrand concentrates are useful sources of exogenous VWF for the treatment of patients unresponsive to desmopressin, ${ }^{7}$ but may cause thrombocytopenia in some subgroups.

Female patients with vWD may need treatment before and after delivery as well as after other minor and major surgical procedures. ${ }^{6}$ Subsequently our patient received counselling, hepatitis B vaccination subcutaneously, and a "green card" which gives details of her vWF levels and activity as well as a contact telephone number.

\section{Conclusion}

The value of aspirating traumatic elbow effusions such as may occur in cases of radial head fracture has previously been described. ${ }^{9}$ This case emphasises the value of aspirating atraumatic elbow effusions. Aspiration in this woman revealed an unsuspected haemarthrosis which guided us to the correct diagnosis. Had this woman's elbow not been aspirated, it is likely to have resolved and the opportunity for making a diagnosis lost.

1 Gaston SR, Smith FM, Baab OD. Adult injuries of the radial head and neck. Am $\mathcal{F}$ Surg 1949;78:631-5.

2 Jastremski MS, Dumas M, Penalver L. Emergency procedures. 1st Ed. Philadelphia: WB Saunders, 1992:254-5.

3 Rinder MR, Richard RE, Rinder HM. Acquired von Rinder MR, Richard RE, Rinder HM. Acquired von
Willebrand's disease: a concise review. Am $\mathscr{f}$ Haematol 1997:54:139 dis

4 Hamidou M, Agard C, Fressinaud E, et al. Acquired Hamidou M, Agard C, Fressinaud E, et al. Acquired
Willebrand syndrome in lymphoproliferative disorders. Presse Med 1997;26:12-14

5 Hoffbrand AV, Lewis SM. Postgraduate haematology. 3rd Ed. Oxford: Heinemann, 1989: 643-8.

6 Beutler E, Williams WJ, Lichtman MA. Williams hematology. 5th Ed. New York: McGraw-Hill, 1995: 369-73.

7 Ewenstein BM. von Willebrand's disease. Annu Rev Med 1997;48:525-42.

8 Nichols WC, Ginsberg D. von Willebrand's disease. Medicine (Baltimore) 1997;76:1-20.

9 Holdsworth BJ, Clement DA, Rothwell PNR. Fractures of the radial head-the benefit of aspiration: a prospective controlled trial. Injury 1987;18:44-7.

10 Dooley JF, Angus PD. The importance of elbow aspiration when treating radial head fractures. Arch Emerg Med 1991; 8:117-21. 